\title{
Total synthesis of neopeltolide and analogs
}

\author{
Yubo Cui, Wangyang Tu, and Paul E. Floreancig \\ Department of Chemistry, University of Pittsburgh, Pittsburgh, Pennsylvania 15260, USA
}

\begin{abstract}
Neopeltolide, a potent cytotoxin from a Carribean sponge, was synthesized through a brief sequence that highlights the use of ethers as oxocarbenium ion precursors. Other key steps include an acid-mediated etherification and sequence that features a Sonogashira reaction, an intramolecular alkyne hydrosilylation reaction, and a Tamao oxidation. The alkene that is required for the oxidative cyclization can be hydrogenated to provide access to the natural product or an epimer, or can be epoxidized or dihydroxylated to form polar analogs.
\end{abstract}

\section{Keywords}

Synthesis; Cations; Macrocycle; Oxidation; Analogs

\section{Introduction}

In 2007 Wright and co-workers reported1 the isolation of neopeltolide from the sponge Daedolapelta of the Neopeltodae family off the Jamaican coast. This compound was initially assigned as structure $\mathbf{1}$ based on extensive NMR analysis. Neopeltolide exhibits potent cytotoxic and anti-fungal activity, with $\mathrm{IC}_{50}$ values of $<10 \mathrm{nM}$ against a number of cancer cell lines and an MIC of $0.62 \mu \mathrm{g} / \mathrm{mL}(1 \mu \mathrm{M})$ against Candida albicans. Although neopeltolide is structurally less complex than the related macrolide leucascandrolide A (2),2 a well studied synthetic target, 3 its biological activity is comparable or superior. Neopeltolide's interesting biological activity and accessible structure have inspired extensive interest in its total synthesis. Panek4 and Scheidt5 independently reported total syntheses of neopeltolide, and through these efforts showed that the correct structure is $\mathbf{3}$. Since these reports a number of elegant total and formal syntheses have been reported.6

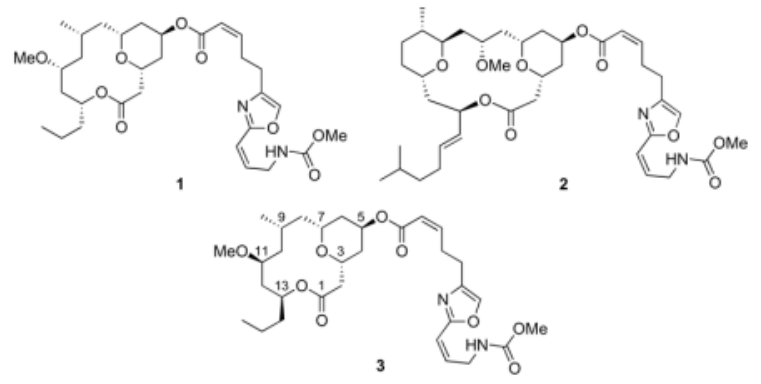

Supplementary Material

Copies of ${ }^{1} \mathrm{H}$ and ${ }^{13} \mathrm{C}$ NMR spectra for all new compounds can be found online.

Publisher's Disclaimer: This is a PDF file of an unedited manuscript that has been accepted for publication. As a service to our customers we are providing this early version of the manuscript. The manuscript will undergo copyediting, typesetting, and review of the resulting proof before it is published in its final citable form. Please note that during the production process errors may be discovered which could affect the content, and all legal disclaimers that apply to the journal pertain. 
Synthesis has allowed for further biological studies of neopeltolide. Kozmin and co-workers identified cytochrome $b c_{1}, 6 \mathrm{~d}$ a mitochondrial enzyme that is involved in ATP synthesis, as a viable cellular target for $\mathbf{2}$ and 3. Crews, Scheidt, and coworkers reported6h that neopeltolide exhibits cell line selectivity for its cytotoxic activity. Several groups have prepared neopeltolide analogs and studied their cytotoxicity. These efforts have shown that the oxazole-containing side chain, while showing no activity on its own, is essential for activity and significant changes to this unit are generally not tolerated.6g,h Several stereochemical changes in the lactone core are tolerated, though $\mathbf{1}$ is nearly two orders of magnitude less active than 3.6g,h,i Removing the C9 methyl group or the C11 methoxy group does not dramatically alter activity.6k This is significant because these analogs can be prepared more readily than neopeltolide. No efforts toward altering the physical properties of neopeltolide through introducing hydrophilic functional groups have been reported.

Our interest in neopeltolide arose from a desire to apply our recently-developed oxidative cyclization protocol7 in the context of natural product synthesis. This method proceeds through DDQ-mediated carbon-hydrogen bond cleavage of benzylic or allylic ethers to form oxocarbenium ions. These electrophiles react with appended nucleophiles to form tetrahydropyrans with excellent stereocontrol. The use of oxidative carbon hydrogen bond cleavage also allows for the formation of macrocyclic oxocarbenium ions through cyclic ether oxidation (Scheme 1).8 These intermediates, which can be utilized for stereoselective transannular reactions, have been prepared previously through conventional intramolecular condensation reactions between alcohols or silyl ethers and aldehydes.5,6a, 1,9 The generality of this approach, however, has not been established. Rychnovsky and co-workers, for example, conducted computational studies to show that the efficient formation of the macrocyclic oxocarbenium ion in their kendomycin synthesis arose from conformational preorganization of the hydroxyl and aldehyde groups.9d Oxidizing a pre-formed macrocycle represents a potentially more general approach to this type of intermediate.

The formation of the neopeltolide macrolactone from a macrocyclic allylic ether precursor is advantageous from a strategic perspective since etherification can be used as an early stage fragment coupling reaction. The stable ether linkage obviates the need for protecting groups during the sequence and for the introduction of activating groups for electrophile formation. In this manuscript we report the total synthesis of neopeltolide through an oxidatively generated macrocyclic oxocarbenium ion. Key steps in the sequence include fragment coupling through a BrØnsted acid-mediated etherification process and a Sonogashira reaction, and a regioselective alkyne hydration through hydrosilylation. We also report that the alkene in the cyclization product can be functionalized with good to excellent stereochemical control en route to the natural product and analogs.

\section{Results and Discussion}

\subsection{Retrosynthetic analysis}

We designed our synthesis of $\mathbf{3}$ to proceed through $\mathbf{4}$, a known precursor5, 6 e to the natural product (Scheme 2). This bridged bicycle can be accessed from $\mathbf{5}$ through oxidative cyclization and stereoselective alkene reduction. The macrocycle is derived from diester $\mathbf{6}$, which in turn can be prepared from readily-accessible subunits $\mathbf{7 , 8}$, and $\mathbf{9}$.

\subsection{Neopeltolide synthesis}

The synthesis of 7 (Scheme 3) proceeded through 2-butyn-1-ol hydroalumination with RedAl10 followed by quenching with $\mathrm{I}_{2}$. The desired trichloroacetimidate was formed by exposing the iodoallylic alcohol to $\mathrm{NaH}$ and $\mathrm{Cl}_{3} \mathrm{CCN}$. Epoxide $\mathbf{8}$ is commercially available in enantiomerically pure form, though cost constraints mandate that it be synthesized rather 
than purchased. Epoxidation of ethyl 3-butenoate with $m$-CPBA followed by hydrolytic kinetic resolution11 with Jacobsen's $(S, S)$-salenCo(III) catalyst provided 8 in suitable yield. The epoxide was opened with lithium trimethylsilylacetylide and $\mathrm{Et}_{2} \mathrm{AlCl} 12$ to provide alcohol 10 in $85 \%$ yield. This unit was prepared in $>99 \%$ ee as determined by Mosher ester analysis.13 Epoxide 9 is also commercially available in enantiomerically pure form but expense again dictated that it be prepared through hydrolytic kinetic resolution of the less expensive racemic epoxide with the $(S, S)$-salenCo(III) catalyst. Opening the epoxide with the ethylene diamine complex of lithium acetylide14 yielded $\mathbf{1 1}$ in $71 \%$ yield and in $>99 \%$ ee (as determined by Mosher ester analysis). Attempts to prepare $\mathbf{1 1}$ directly through the addition of allenyl tributyltin to butanal in the presence of $(R)$-BINOL and $\operatorname{Ti}\left(\mathrm{O}^{i} \operatorname{Pr}\right)_{4} 15$ were productive with respect to overall yield, though the enantiomeric excess of $67 \%$ was not suitable for the synthesis.

We initially attempted to use TMSOTf to promote the ether linkage formation 16 between 7 and $\mathbf{1 0}$ (Scheme 4) to avoid the use of harshly basic Williamson ether synthesis conditions that could cause $\mathbf{1 0}$ to undergo a retro aldol reaction. Significant alkene isomerization was observed, however, leading to an inseparable 4:1 mixture of geometrical isomers $\mathbf{1 2}$ and $\mathbf{1 3}$ in $74 \%$ yield. During the course of an extensive optimization effort that focused on concentration, stoichiometry, and temperature variations, we observed that the addition of 2,6-di-tert-butylpyridine completely suppressed the etherification reaction. This indicated that adventitious $\mathrm{TfOH}$ was the real catalyst for the reaction. Combining 10 with an excess of $\mathbf{7}$ in the presence of $15 \mathrm{~mol} \% \mathrm{TfOH}$ resulted in the isolation of a 7.3:1 mixture of $\mathbf{1 2}$ and 13 in $77 \%$ yield.

The remaining carbons for the neopeltolide macrolactone could, in principle, be introduced through a Sonogashira coupling17 between 11 and 12 (Scheme 5). The yield of enyne 14, however, never exceeded $35 \%$ despite repeated attempts to optimize the reaction conditions with respect to palladium catalyst, solvent, and amine. We postulated that the inefficiency derived from the free hydroxyl group in 11, and this was confirmed when we subjected silyl ether 15 to standard Sonogashira conditions with 12 and isolated enyne 16 in 89\% yield. While this yield was acceptable, the use of a silyl ether solely as a protecting group was not desirable. In consideration our plan to perform a regioselective alkyne hydration reaction through intramolecular hydrosilylation, we studied the possibility of using dialkylsilyl ethers in the coupling reaction. While the dimethylsilyl and diphenylsilyl ethers of $\mathbf{1 1}$ proved to be too labile to survive the coupling, diisopropylsilyl ether 17, prepared in $77 \%$ yield by treating 11 with ${ }^{i} \mathrm{Pr}_{2} \mathrm{Si}(\mathrm{H}) \mathrm{Cl}$ and imidazole, coupled with 12 to form enyne 18 in $89 \%$ yield.

The regioselective alkyne hydration reaction required that the sequence 18 of intramolecular hydrosilylation and Tamao oxidation proceed without isomerization of the product $\beta, \gamma$ unsaturated ketone to the conjugated isomer. The hydrosilylation of $\mathbf{1 8}$ proceeded quite smoothly with Pt(DVDS)19 (DVDS = divinyl dimethyldisoloxane) to form siloxane 19. The isopropyl groups in $\mathbf{1 9}$ create greater steric congestion than the methyl groups that are generally used in these reactions, dictating that the Tamao oxidation 20 be conducted under than unusually harsh conditions. Extensive optimization led to the identification of a suitable protocol in which 19 was exposed to a mixture of $\mathrm{Bu}_{4} \mathrm{NF}, \mathrm{KF}, \mathrm{KHCO}_{3}$, and aqueous $\mathrm{H}_{2} \mathrm{O}_{2}$ in THF and DMF at $40^{\circ} \mathrm{C}$ to yield $\mathbf{2 0}$ in $57 \%$ yield as an acceptable $11: 1$ mixture with conjugated isomer 21. These conditions also led to concomitant cleavage of the alkynylsilane group. The alkene stereoisomer that had been carried through the sequence since the etherification reaction was easily be removed at this stage. Attempts to improve the yield of the hydration by conducting a trans-hydrosilylation with $\left[\left(\mathrm{C}_{6} \mathrm{H}_{6}\right) \mathrm{RuCl}_{2}\right]_{2} 21$ were unsuccessful. 
The remainder of the sequence to form the macrolactone substrate (Scheme 7) proceeded with little incident. Reduction of $\mathbf{2 0}$ under Evans-Tischenko22 conditions provided hydroxy ester $\mathbf{2 2}$ in $\mathbf{7 7 \%}$ yield as a single stereoisomer. Conjugated isomer $\mathbf{2 1}$ was unreactive in this reaction and was easily separated. This transformation is ideally suited for neopeltolide synthesis, as observed in most approaches to this structure, because it establishes the appropriate stereochemical relationship between $\mathrm{C} 11$ and $\mathrm{C} 13$ while selectively protecting the C13 hydroxyl group. Selective protection allows for efficient methylation of the C11 hydroxyl group to form 22. Cleaving both ester groups and lactonizing under Yamaguchi's conditions 23 provided $\mathbf{2 3}$ in $71 \%$ overall yield. Exposing 23 to HOAc and [ $p$ cymene) $\left.\mathrm{RuCl}_{2}\right]_{2} 24$ provided cyclization substrates $\mathbf{5}$ along with regioisomer $\mathbf{2 4}$ as an inseparable 5:1 mixture in $82 \%$ yield. We have modified the reported protocol for enol acetate formation to include 1-decyne. This promotes greater reproducibility for the reaction by using a sacrificial alkyne to aid in the generation of the catalytically relevant ruthenium phosphine complex.

The oxidative cyclization of $\mathbf{5}$ (Scheme 8) was significantly slower than previous cyclization reactions of acyclic allylic ethers that contain trisubstituted alkenes.7 Two factors could lead to the slow kinetics. The proximity of the ether oxygen to the electron withdrawing carboxyl group reduces its capacity to stabilize the intermediate oxocarbenium ion. We have observed that these reactions are dependent upon the oxidation potential of the substrate and the stability of the intermediate carbocation.25 Inductively destabilizing the cation, therefore, slows the reaction. The macrocycle also could adapt a conformation that inhibits proper alignment between the cleaving carbon-hydrogen bond and the $\pi$-bond of the alkene. Stereoelectronic effects have been established as an important kinetic factor in other oxidative cleavage reactions. 26 The reaction proceeded to completion after $18 \mathrm{~h}$ at $\mathrm{rt}$ by using 3 eq DDQ. This provided a 57\% yield of bicyclic tetrahydropyran 25 . In consideration of the fact that the starting material was an 84:16 mixture of enol acetate regioisomers, this yield could be extrapolated to $65 \%$ if pure $\mathbf{5}$ were used in the reaction. No 5-endocyclization product from the reaction of $\mathbf{2 4}$ was isolated.

Completing the synthesis (Scheme 9) required that the $\Delta 8,9$ alkene be reduced with high facial control. A crystal structure 27 of $\mathbf{2 5}$ showed that the molecule prefers a curved conformation in which the sterically more-accessible convex face is the should react with $\mathrm{H}_{2}$ to provide the desired stereoisomer. Indeed, subjecting 25 to $\mathrm{H}_{2}$ and $\mathrm{Pd} / \mathrm{C}$ provided $\mathbf{4}$ in $74 \%$ yield. A small amount ( $<10 \%$, impure) of the stereoisomer at $\mathrm{C} 9$ was also isolated. The conversion of 4 to neopeltolide has been reported,5, $6 \mathrm{f}$ but we completed the synthesis to have the natural product for subsequent biological studies. Reduction of 4 with $\mathrm{NaBH}_{4}$ in $\mathrm{MeOH}$ followed by Mitsunobu esterification 28 with acid $\mathbf{2 6}$ (prepared according to the protocol of Wipf and Graham29) provided 3.

\subsection{Analog synthesis}

The presence of the $\Delta 8,9$ alkene in $\mathbf{2 5}$ creates opportunities for analog synthesis. Simply reducing the $\mathrm{C} 5$ carbonyl group of $\mathbf{2 5}$ with $\mathrm{NaBH}_{4}$ followed by appending the side chain provided dehydroneopeltolide $\mathbf{2 7}$ (Scheme 10). Although this structure is not likely to differ from neopeltolide with respect to physical properties or biological activity, the removal of one step in the sequence improves analog accessibility.

We subjected $\mathbf{2 5}$ to hydrogenation in the presence of Crabtree's catalyst30 in an effort to determine whether we could exploit reagent coordination to the tetrahydropyranyl oxygen to functionalize the alkene from the convex face (Scheme 11). While the diastereoselectivity for the reaction was low ( 1.4:1), major product $\mathbf{2 8}$, the C9-epimer of $\mathbf{4}$, was isolated in a reasonable 54\% yield. Despite the low selectivity, this result suggests that future analogs can be accessed through coordinated delivery of reagents 31 to the less accessible face of the 
alkene. Reduction of $\mathbf{2 8}$ with $\mathrm{NaBH}_{4}$ followed by esterification with $\mathbf{2 6}$ provided C9-epineopeltolide 29.

The alkene provides opportunities for introducing polar groups that could improve physical properties such as water solubility. Exposing $\mathbf{2 5}$ to $\mathrm{OsO}_{4}$ and pyridine, followed by osmate ester cleavage with NMO yielded diol $\mathbf{3 0}$ in $75 \%$ yield as a single diastereomer. This reaction required stoichiometric $\mathrm{OsO}_{4}$ to proceed at a reasonable rate, though at a larger scale the $\mathrm{OsO}_{4}$ loading could conceivably be lowered. Ketone reduction and acylation provided a 50\% yield of dihydroxyneopeltolide 31 . We approached the epoxide analog by reducing 25 with $\mathrm{NaBH}_{4}$ followed by exposing the resulting alcohol to $m$-CPBA to provide 32. Conducting the reduction prior to epoxidation averted the potential for $\mathbf{2 5}$ to undergo a competitive Bayer-Villiger reaction. Acylation gave epoxyneopeltolide $\mathbf{3 3}$ in $66 \%$ yield.

\section{Summary and Conclusions}

We have shown that our method for oxidative carbocation formation in a macrocycle can be applied to the total synthesis of the potent cytotoxin neopeltolide. The use of a relatively inert ether as a precursor to an oxocarbenium ion obviates the need for step investment with respect to protecting groups and/or activating groups, leading to a brief overall sequence. This work also highlights the versatility of alkynes in complex molecule synthesis 32 (coupling through the Sonogashira reaction, hydration to form a ketone, and acetoxylation to form an enol acetate). While neopeltolide does not contain the alkenyl group that is required to conduct the oxidative cyclization, the unsaturation can be exploited to provide a number of interesting analogs. Hydrogenation can be conducted with $\mathrm{Pd} / \mathrm{C}$ or Crabtree's catalyst provides the natural product or an epimer. Retaining the alkene provide a structure that can be accessed in one fewer step. Dihydroxylation and epoxidation yield analogs that are more polar than the natural product. We have initiated studies to evaluate the biological activities of these and other analogs. The results of these studies will be reported elsewhere.

\section{Experimental Section}

\subsection{General experimental}

Proton $\left({ }^{1} \mathrm{H}\right.$ NMR $)$ and carbon $\left({ }^{13} \mathrm{C}\right.$ NMR $)$ nuclear magnetic resonance spectra were recorded on Bruker Avance 300 spectrometer at $300 \mathrm{MHz}$ and $75 \mathrm{MHz}$, respectively. The chemical shifts are given in parts per million $(\mathrm{ppm})$ on the delta $(\delta)$ scale. Tetramethylsilane (TMS) or the solvent peak was used as a reference value, for ${ }^{1} \mathrm{H}$ NMR: TMS (in $\mathrm{CDCl}_{3}$ ) $=0.00 \mathrm{ppm}$, $\mathrm{CD}_{3} \mathrm{OD}=3.31$, for ${ }^{13} \mathrm{C}$ NMR: TMS (in $\mathrm{CDCl}_{3}$ ) $=0.00, \mathrm{CD}_{3} \mathrm{OD}=49.00$. Data are reported as follows: $(\mathrm{s}=$ singlet; $\mathrm{d}=$ doublet; $\mathrm{t}=$ triplet; $\mathrm{q}=$ quartet; $\mathrm{dd}=$ doublet of doublets; $\mathrm{dt}=$ doublet of triplets; $\mathrm{br}=$ broad). High resolution and low resolution mass spectra were recorded on a VG 7070 spectrometer. Infrared (IR) spectra were collected on a Mattson Cygnus 100 spectrometer. Optical rotations were measured on a Perkin-Elmer 241 polarimeter. Samples for IR were prepared as a thin film on a $\mathrm{NaCl}$ plate by dissolving the compound in $\mathrm{CH}_{2} \mathrm{Cl}_{2}$ and then evaporating the $\mathrm{CH}_{2} \mathrm{Cl}_{2}$. Analytical TLC was performed on E. Merck pre-coated $(25 \mathrm{~mm})$ silica gel $60 \mathrm{~F}-254$ plates. Visualization was done under UV $(254 \mathrm{~nm})$. Flash chromatography was done using ICN SiliTech 32-63 60 A silica gel. Methylene chloride was distilled under $\mathrm{N}_{2}$ from $\mathrm{CaH}_{2}$. Reagent grade ethyl acetate, diethyl ether, pentane and hexanes (commercial mixture) were purchased from EM Science and used as is for chromatography. Benzene was dried with 4A molecular sieves. THF was distilled from sodium. Other reagents were obtained from commercial source without further purification. All reactions were performed in oven or flame-dried glassware with magnetic stirring unless otherwise noted. The synthesis and characterization of compounds $4, \mathbf{5}, \mathbf{7}, \mathbf{1 0}$, 12, 18, 20, 22, 23, and 25 have previously been reported. 


\subsection{General procedure for macrocyclic ketone reduction}

To the macrocyclic ketone $(0.020 \mathrm{mmol})$ in $\mathrm{MeOH}(0.5 \mathrm{~mL})$ at $0{ }^{\circ} \mathrm{C}$ was added $\mathrm{NaBH}_{4}$ $(0.040 \mathrm{mmol})$ was added. After $10 \mathrm{~min}, \mathrm{AcOH}(0.40 \mathrm{mmol})$ was added and the reaction was concentrated under vacuum. The resulting residue was purified by flash column chromatography to afford the desired macrocyclic alcohol.

\subsection{General procedure for Mitsunobu acylation}

Tohe macrocyclic alcohol $(0.019 \mathrm{mmol}), 26(0.078 \mathrm{mmol})$, and $\mathrm{PPh}_{3}(0.086 \mathrm{mmol})$ in benzene $(0.5 \mathrm{~mL})$ was added DIAD $(0.086 \mathrm{mmol})$. After ten minutes the reaction was concentrated under vacuum. The resulting residue was purified by flash column chromatography to afford the desired product.

\subsection{Procedures and characterization data}

4.4.1. (1R,5S,7S,9S,11R,13S)-13-hydroxy-7-methoxy-9-methyl-5-propyl-4,15dioxabicyclo[9.3.1]pentadecan-3-one-The general ketone reduction protocol was followed with $4(6.5 \mathrm{mg}, 0.020 \mathrm{mmol})$ and $\mathrm{NaBH}_{4}(1.6 \mathrm{mg}, 0.042 \mathrm{mmol})$. Flash column chromatography (50\% EtOAc in hexanes) yielded the desired product $(6.2 \mathrm{mg}, 95 \%) .{ }^{1} \mathrm{H}$ NMR (300 MHz, $\left.\mathrm{CDCl}_{3}\right) \delta 5.12-5.21(\mathrm{~m}, 1 \mathrm{H}), 3.75-3.87(\mathrm{~m}, 1 \mathrm{H}), 3.73$ (ddd, $J=2.0,4.4$, $10.9 \mathrm{~Hz}, 1 \mathrm{H}), 3.59(\mathrm{t}, J=9.4 \mathrm{~Hz}, 1 \mathrm{H}), 3.32(\mathrm{~s}, 3 \mathrm{H}), 3.18(\mathrm{t}, J=9.3 \mathrm{~Hz}, 1 \mathrm{H}), 2.63(\mathrm{dd}, J=$ $4.4,14.5 \mathrm{~Hz}, 1 \mathrm{H}), 2.44(\mathrm{dd}, J=10.7,14.5 \mathrm{~Hz}, 1 \mathrm{H}), 1.99(\mathrm{ddd}, J=1.8,1.8,11.5 \mathrm{~Hz}, 1 \mathrm{H})$, 1.81-1.92 (m, 2H), 1.43-1.78 (m, 5H), 1.12-1.41 (m, 6H), $1.0(\mathrm{~d}, J=6.7 \mathrm{~Hz}, 3 \mathrm{H}), 0.92(\mathrm{t}, J$ $=7.3 \mathrm{~Hz}, 3 \mathrm{H}) ;{ }^{13} \mathrm{C} \mathrm{NMR}\left(75 \mathrm{MHz}, \mathrm{CDCl}_{3}\right) \delta 170.8,78.6,75.6,73.3,72.3,68.1,56.2,44.1$, 42.2, 42.2, 41.9, 40.7, 40.0, 36.9, 31.2, 25.5, 19.0, 13.9; IR (film) 3416, 2918, 2871, 1730, $1650,1459,1087 \mathrm{~cm}^{-1}$; HRMS (ESI) calcd. for $\mathrm{C}_{18} \mathrm{H}_{32} \mathrm{O}_{5} \mathrm{Na}\left([\mathrm{M}+\mathrm{Na}]^{+}\right) 351.2147$, found $351.2159 ;[\alpha]_{\mathrm{D}}^{25}=+17.1\left(\mathrm{CHCl}_{3}, \mathrm{c}=0.2\right)$.

4.4.2. Synthesis of neopeltolide (3)-The general Mitsunobu acylation procedure was followed with the macrocyclic alcohol $(6.2 \mathrm{mg}, 0.019 \mathrm{mmol}), 26(22.0 \mathrm{mg}, 0.078 \mathrm{mmol})$, $\mathrm{Ph}_{3} \mathrm{P}(11.4 \mathrm{mg}, 0.086 \mathrm{mmol})$ and DIAD $(16.8 \mu \mathrm{L}, 0.086 \mathrm{mmol})$. Flash column chromatography (30\% EtOAc in hexanes) yielded neopeltolide (10.5 mg, 93\%). ${ }^{1} \mathrm{H}$ NMR $\left(300 \mathrm{MHz}, \mathrm{CD}_{3} \mathrm{OD}\right) \delta 7.66(\mathrm{~s}, 1 \mathrm{H}), 6.32-6.41(\mathrm{~m}, 1 \mathrm{H}), 6.28(\mathrm{dt}, J=2.1,13.8 \mathrm{~Hz}, 1 \mathrm{H}), 6.03$ (pentet, $J=6.0 \mathrm{~Hz}, 1 \mathrm{H}), 5.88(\mathrm{~d}, J=11.6 \mathrm{~Hz}, 1 \mathrm{H}), 5.20(\mathrm{t}, J=2.8 \mathrm{~Hz}, 1 \mathrm{H}), 5.12-5.22(\mathrm{~m}$, $1 \mathrm{H}), 4.30(\mathrm{dd}, J=1.4,4.2 \mathrm{~Hz}, 2 \mathrm{H}), 4.06(\mathrm{t}, J=9.3 \mathrm{~Hz}, 1 \mathrm{H}), 3.70(\mathrm{~s}, 1 \mathrm{H}), 3.65(\mathrm{~s}, 3 \mathrm{H}), 3.56$ $(\mathrm{t}, J=9.0 \mathrm{~Hz}, 1 \mathrm{H}), 3.28(\mathrm{~s}, 3 \mathrm{H}), 3.01(\mathrm{dd}, J=7.6,15.1 \mathrm{~Hz}, 2 \mathrm{H}), 2.71(\mathrm{~s}, 1 \mathrm{H}), 2.70(\mathrm{dt}, J=$ $4.4,14.7 \mathrm{~Hz}, 1 \mathrm{H}), 2.23(\mathrm{dd}, J=11.0,14.7 \mathrm{~Hz}, 1 \mathrm{H}), 1.73-1.90(\mathrm{~m}, 2 \mathrm{H}), 1.65-1.73(\mathrm{~m}, 2 \mathrm{H})$, $1.44-1.60(\mathrm{~m}, 5 \mathrm{H}), 1.26-1.44(\mathrm{~m}, 6 \mathrm{H}), 1.07-1.18(\mathrm{~m}, 1 \mathrm{H}), 0.97(\mathrm{~d}, J=6.3,3 \mathrm{H}), 0.92(\mathrm{~d}, \mathrm{~J}=$ $13.6 \mathrm{~Hz}, 3 \mathrm{H}) ;{ }^{13} \mathrm{C}$ NMR $\left(75 \mathrm{MHz}, \mathrm{CD}_{3} \mathrm{OD}\right) \delta 173.1,166.9,161.9,159.5,150.0,142.3$, 139.3, 136.0, 121.7, 116.0, 77.2, 77.1, 74.0, 71.4, 69.2, 56.4, 52.6, 45.3, 43.5, 43.3, 41.1, 38.0, 37.6, 37.4, 36.2, 32.6, 29.0, 26.4, 26.0, 20.0, 14.2; IR (film) 3357, 2954, 2922, 2854 , 1719, 1646, 1537, 1458, 1376, 1342, 1249, 1178, 1064, 994, $777 \mathrm{~cm}^{-1}$; HRMS (ESI) calcd. for $\mathrm{C}_{31} \mathrm{H}_{46} \mathrm{~N}_{2} \mathrm{O}_{9} \mathrm{Na}\left([\mathrm{M}+\mathrm{Na}]^{+}\right) 613.3101$, found 613.3076; $[\alpha]_{\mathrm{D}}{ }^{25}=+17.5(\mathrm{MeOH}, \mathrm{c}=$ $0.24)$.

4.4.3. (1R,5S,7S,11S,13R,Z)-13-hydroxy-7-methoxy-9-methyl-5-propyl-4,15dioxabicyclo[9.3.1]pentadec-9-en-3-one-The general ketone reduction protocol was followed with 25 (14.9 mg, $0.046 \mathrm{mmol})$ and $\mathrm{NaBH}_{4}(3.6 \mathrm{mg}, 0.095 \mathrm{mmol})$. Flash column chromatography (50\% EtOAc in hexanes) yielded the desired product $(12.6 \mathrm{mg}, 84 \%) .{ }^{1} \mathrm{H}$ NMR $\left(300 \mathrm{MHz}, \mathrm{CDCl}_{3}\right) \delta 5.31-5.37(\mathrm{~m}, 1 \mathrm{H}), 5.30(\mathrm{~d}, J=7.2 \mathrm{~Hz}, 1 \mathrm{H}), 3.82-3.93(\mathrm{~m}, 3 \mathrm{H})$, $3.49-3.56(\mathrm{~m}, 1 \mathrm{H}), 3.36(\mathrm{~s}, 3 \mathrm{H}), 2.63(\mathrm{dd}, J=3.8,15.1 \mathrm{~Hz}, 1 \mathrm{H}), 2.51(\mathrm{dd}, J=11.1,15.1 \mathrm{~Hz}$, $1 \mathrm{H}), 2.33(\mathrm{~d}, J=13.3 \mathrm{~Hz}, 1 \mathrm{H}), 1.95-2.05(\mathrm{~m}, 3 \mathrm{H}), 1.86(\mathrm{~d}, J=0.6 \mathrm{~Hz}, 3 \mathrm{H}), 1.81-1.89(\mathrm{~m}$, $1 \mathrm{H}), 1.64-1.74(\mathrm{~m}, 1 \mathrm{H}), 1.47-1.59(\mathrm{~m}, 2 \mathrm{H}), 1.44(\mathrm{~s}, 1 \mathrm{H}), 1.18-1.40(\mathrm{~m}, 3 \mathrm{H}), 0.92(\mathrm{t}, J=7.2$ 
$\mathrm{Hz}, 3 \mathrm{H}) ;{ }^{13} \mathrm{C} \mathrm{NMR}\left(75 \mathrm{MHz}, \mathrm{CDCl}_{3}\right) \delta 170.3,146.9,125.1,81.8,74.1,72.4,72.0,68.1$, 57.9, 43.3, 42.1, 41.8, 40.5, 40.3, 37.4, 25.2, 18.7, 13.9; IR (film) 3422, 2959, 2923, 2854, 1732, 1654, 1454, 1373, 1315, 1264, 1195, 1080, 1035, 981, 939, 842, $755 \mathrm{~cm}^{-1}$; HRMS (ESI) calcd. for $\mathrm{C}_{18} \mathrm{H}_{30} \mathrm{O}_{5} \mathrm{Na}\left([\mathrm{M}+\mathrm{Na}]^{+}\right) 349.1991$, found $349.1992 ;[\alpha]_{\mathrm{D}}{ }^{25}=-47.0$ $\left(\mathrm{CHCl}_{3}, \mathrm{c}=0.38\right)$.

4.4.4. Dehydroneopeltolide (27)—The general Mitsunobu acylation protocol was followed with the macrocyclic alcohol $(6.8 \mathrm{mg}, 0.021 \mathrm{mmol}), \mathbf{2 6}(23.0 \mathrm{mg}, 0.083 \mathrm{mmol})$, $\mathrm{Ph}_{3} \mathrm{P}(23.5 \mathrm{mg}, 0.090 \mathrm{mmol})$ and DIAD $(17.8 \mu \mathrm{L}, 0.090 \mathrm{mmol})$. Flash column chromatography (30\% EtOAc in hexanes) yielded dehydro-neopeltolide $(8.6 \mathrm{mg}, 70 \%) .{ }^{1} \mathrm{H}$ NMR $\left(300 \mathrm{MHz}, \mathrm{CD}_{3} \mathrm{OD}\right) \delta 7.67(\mathrm{~s}, 1 \mathrm{H}), 6.34-6.43(\mathrm{~m}, 1 \mathrm{H}), 6.28(\mathrm{dt}, J=2.0,12.0 \mathrm{~Hz}$, $1 \mathrm{H}), 6.05$ (pentet, $J=6.0 \mathrm{~Hz}, 1 \mathrm{H}), 5.90(\mathrm{dt}, J=1.5,11.5 \mathrm{~Hz}, 1 \mathrm{H}), 5.25-5.33(\mathrm{~m}, 1 \mathrm{H}), 5.27$ (t, $J=2.8 \mathrm{~Hz}, 1 \mathrm{H}), 5.22(\mathrm{~d}, J=6.7 \mathrm{~Hz}, 1 \mathrm{H}), 4.31(\mathrm{~d}, J=4.7 \mathrm{~Hz}, 2 \mathrm{H}), 4.19-4.28(\mathrm{~m}, 2 \mathrm{H})$, $3.66(\mathrm{~s}, 3 \mathrm{H}), 3.58-3.65(\mathrm{~m}, 1 \mathrm{H}), 3.34(\mathrm{~s}, 3 \mathrm{H}), 3.03(\mathrm{ddd}, J=1.4,7.7,7.7 \mathrm{~Hz}, 2 \mathrm{H}), 2.73(\mathrm{t}, \mathrm{J}=$ $7.0 \mathrm{~Hz}, 2 \mathrm{H}), 2.69(\mathrm{dd}, \mathrm{J}=3.4,10.2 \mathrm{~Hz}, 1 \mathrm{H}), 2.27-2.38(\mathrm{~m}, 2 \mathrm{H}), 1.95(\mathrm{dd}, J=10.4,13.6 \mathrm{~Hz}$, $1 \mathrm{H}), 1.84(\mathrm{~s}, 3 \mathrm{H}), 1.62-1.88(\mathrm{~m}, 5 \mathrm{H}), 1.49-1.58(\mathrm{~m}, 3 \mathrm{H}), 1.23-1.30(\mathrm{~m}, 3 \mathrm{H}), 0.95(\mathrm{t}, J=7.3$ $\mathrm{Hz}, 3 \mathrm{H}) ;{ }^{13} \mathrm{C}$ NMR $\left(75 \mathrm{MHz}, \mathrm{CD}_{3} \mathrm{OD}\right) \delta 172.7,166.9,162.0,159.7,150.1,148.0,142.3$, 139.3, 136.0, 127.0, 121.8, 116.0, 83.4, 75.2, 71.3, 71.1, 69.1, 58.2, 52.7, 44.2, 43.3, 42.5, 41.1, 38.5, 36.3 35.9, 29.1, 26.5, 25.8, 19.9, 14.3; IR (film) 3351, 2957, 2923, 1719, 1521, $1458,1268,1170,1097,1072,892,818,776 \mathrm{~cm}^{-1}$; HRMS (ESI) calcd. for $\mathrm{C}_{31} \mathrm{H}_{44} \mathrm{~N}_{2} \mathrm{O}_{9} \mathrm{Na}$ $\left([\mathrm{M}+\mathrm{Na}]^{+}\right) 611.2945$, found 611.2997; $[\alpha]_{\mathrm{D}}^{25}=-44.1(\mathrm{MeOH}, \mathrm{c}=0.56)$.

\subsection{5. (1S,5S,7S,9R,11R)-7-methoxy-9-methyl-5-propyl-15-} oxabicyclo[9.3.1]pentadecane-3,13-dione (28)-To $25(6.1 \mathrm{mg}, 0.019 \mathrm{mmol})$ in $\mathrm{CH}_{2} \mathrm{Cl}_{2}(0.2 \mathrm{~mL})$ was added Crabtree's catalyst $(3.2 \mathrm{mg}, 0.004 \mathrm{mmol})$. The flask was quickly evacuated and backfilled with $\mathrm{H}_{2}$, and this process was repeated three times. The reaction mixture was stirred at room temperature for $30 \mathrm{~min}$., then was filtered through Celite, concentrated, and purified by flash chromatography $\left(5 \% \mathrm{Et}_{2} \mathrm{O}\right.$ in $\left.\mathrm{CH}_{2} \mathrm{Cl}_{2}\right)$ to afford the desired product $(3.3 \mathrm{mg}, 54 \%) .{ }^{1} \mathrm{H}$ NMR $\left(300 \mathrm{MHz}, \mathrm{CDCl}_{3}\right) \delta 5.14-5.22(\mathrm{~m}, 1 \mathrm{H}), 3.93-$ $4.02(\mathrm{~m}, 1 \mathrm{H}), 3.69(\mathrm{~m}, 1 \mathrm{H}), 3.32(\mathrm{~s}, 3 \mathrm{H}), 3.23-3.31(\mathrm{~m}, 1 \mathrm{H}), 2.72(\mathrm{dd}, J=4.5,14.4 \mathrm{~Hz}, 1 \mathrm{H})$, $2.46(\mathrm{dd}, J=8.5,14.4 \mathrm{~Hz}, 1 \mathrm{H}), 2.42(\mathrm{dd}, J=4.1,7.0 \mathrm{~Hz}, 1 \mathrm{H}), 2.31(\mathrm{~d}, J=7.8 \mathrm{~Hz}, 2 \mathrm{H}), 1.92$ (dt, $J=2.2,14.8 \mathrm{~Hz}, 1 \mathrm{H}), 1.74-1.83(\mathrm{~m}, 1 \mathrm{H}), 1.43-1.73(\mathrm{~m}, 4 \mathrm{H}), 1.16-1.39(\mathrm{~m}, 6 \mathrm{H}), 0.94$ (d, $J=6.8 \mathrm{~Hz}, 3 \mathrm{H}), 0.92(\mathrm{t}, J=7.3 \mathrm{~Hz}, 3 \mathrm{H}) ;{ }^{13} \mathrm{C} \mathrm{NMR}\left(75 \mathrm{MHz}, \mathrm{CDCl}_{3}\right) \delta 206.4,179.8$, 80.4, 75.0, 73.8, 72.6, 56.3, 48.2, 46.8, 41.7, 41.6, 40.1, 39.0, 37.7, 28.6, 20.9, 18.7, 13.9; IR (film) 2956, 2923, 2853, 1723, 1459, 1370, 1330, 1252, 1185, 1105, 1081, 844, $799 \mathrm{~cm}^{-1}$; HRMS (ESI) calcd. for $\mathrm{C}_{18} \mathrm{H}_{30} \mathrm{O}_{5} \mathrm{Na}\left([\mathrm{M}+\mathrm{Na}]^{+}\right) 349.1991$, found $349.1974 ;[\alpha]_{\mathrm{D}}{ }^{25}=-7.9$ $\left(\mathrm{CHCl}_{3}, \mathrm{c}=0.17\right)$.

\subsection{6. (1R,5S,7S,9R,11R,13S)-13-hydroxy-7-methoxy-9-methyl-5-propyl-15- oxabicyclo[9.3.1]pentadecan-3-one-The general reduction protocol was followed with $28(3.3 \mathrm{mg}, 0.010 \mathrm{mmol})$ and $\mathrm{NaBH}_{4}(1.1 \mathrm{mg}, 0.029 \mathrm{mmol})$. Flash column chromatography (35\% EtOAc in hexanes) yielded the desired product $(3.2 \mathrm{mg}, 96 \%) .{ }^{1} \mathrm{H}$ NMR (300 MHz, $\left.\mathrm{CDCl}_{3}\right) \delta 5.11-5.20(\mathrm{~m}, 1 \mathrm{H}), 3.80-3.86(\mathrm{~m}, 1 \mathrm{H}), 3.69$ (tdd, $J=1.9,4.6$, $11.0 \mathrm{~Hz}, 1 \mathrm{H}), 3.78(\mathrm{tt}, J=2.4,8.7 \mathrm{~Hz}, 1 \mathrm{H}), 3.31(\mathrm{~s}, 3 \mathrm{H}), 3.27(\mathrm{dt}, J=2.0,9.1 \mathrm{~Hz}, 1 \mathrm{H}), 2.64$ (dd, $J=4.6,14.3 \mathrm{~Hz}, 1 \mathrm{H}), 2.41(\mathrm{dd}, J=9.0,14.3 \mathrm{~Hz}, 1 \mathrm{H}), 1.90-1.99(\mathrm{~m}, 2 \mathrm{H}), 1.83-1.88(\mathrm{~m}$, $2 \mathrm{H}), 1.60-1.80(\mathrm{~m}, 3 \mathrm{H}), 1.43-1.60(\mathrm{~m}, 3 \mathrm{H}), 1.13-1.40(\mathrm{~m}, 4 \mathrm{H}), 0.89-0.93(\mathrm{~m}, 6 \mathrm{H}) ;{ }^{13} \mathrm{C}$ NMR (75 MHz, $\left.\mathrm{CDCl}_{3}\right) \delta 170.5,80.5,74.6,72.4,71.5,68.4,56.4,41.8,41.7,41.5,40.3$, 39.6, 39.4, 37.7, 28.7, 21.1, 18.7, 13.9; IR (film) 3363, 3296, 2916, 2852, 1718, 1490, 1457, 1364, 1274, 1256, 1220, 1160, 1108, 1074, 1036, $931 \mathrm{~cm}^{-1}$; HRMS (ESI) calcd. for $\mathrm{C}_{18} \mathrm{H}_{32} \mathrm{O}_{5} \mathrm{Na}\left([\mathrm{M}+\mathrm{Na}]^{+}\right) 351.2147$, found 351.2166; $[\alpha]_{\mathrm{D}}^{25}=-9.6\left(\mathrm{CHCl}_{3}, \mathrm{c}=0.32\right)$.}


4.4.7. 9-epi-neopeltolide (29)—The general Mitsunobu acylation protocol was followed with the alcohol ( $3.1 \mathrm{mg}, 0.0095 \mathrm{mmol}), 26$ (10.5 mg, $0.038 \mathrm{mmol}), \mathrm{Ph}_{3} \mathrm{P}(10.7 \mathrm{mg}, 0.041$ mmol) and DIAD $(8.1 \mu \mathrm{L}, 0.041 \mathrm{mmol})$. Flash column chromatography (30\% EtOAc in hexanes) yielded C9-epi-neopeltolide (3.8 mg, 67\%). ${ }^{1} \mathrm{H}$ NMR $\left(300 \mathrm{MHz}, \mathrm{CD}_{3} \mathrm{OD}\right) \delta 7.65$ $(\mathrm{s}, 1 \mathrm{H}), 6.36(\mathrm{dt}, J=7.4,11.6 \mathrm{~Hz}, 1 \mathrm{H}), 6.26(\mathrm{dt}, J=2.0,11.8 \mathrm{~Hz}, 1 \mathrm{H}), 6.02$ (pentet, $J=6.1$ $\mathrm{Hz}, 1 \mathrm{H}), 5.86(\mathrm{dt}, J=1.6,11.5 \mathrm{~Hz}, 1 \mathrm{H}), 5.22(\mathrm{t}, J=2.8 \mathrm{~Hz}, 1 \mathrm{H}), 5.11-5.20(\mathrm{~m}, 1 \mathrm{H}), 4.29$ (dd, $J=1.5,5.8 \mathrm{~Hz}, 2 \mathrm{H}), 3.95-4.05(\mathrm{~m}, 1 \mathrm{H}), 3.76(\mathrm{t}, J=6.0 \mathrm{~Hz}, 1 \mathrm{H}), 3.64(\mathrm{~s}, 3 \mathrm{H}), 3.29(\mathrm{~s}$, $3 \mathrm{H}), 2.99$ (dd, $J=7.1,7.1 \mathrm{~Hz}, 2 \mathrm{H}), 2.69(\mathrm{t}, J=7.7 \mathrm{~Hz}, 2 \mathrm{H}), 2.65(\mathrm{dd}, J=4.4,9.4 \mathrm{~Hz}, 1 \mathrm{H}$ ), $2.24(\mathrm{dd}, J=9.2,14.4 \mathrm{~Hz}, 1 \mathrm{H}), 1.90(\mathrm{~d}, J=8.9 \mathrm{~Hz}, 1 \mathrm{H}), 1.75-1.84(\mathrm{~m}, 3 \mathrm{H}), 1.39-1.68(\mathrm{~m}$, $4 \mathrm{H}), 1.23-1.39(\mathrm{~m}, 6 \mathrm{H}), 1.22(\mathrm{t}, J=7.2 \mathrm{~Hz}, 2 \mathrm{H}), 1.09-1.19(\mathrm{~m}, 1 \mathrm{H}), 0.91(\mathrm{t}, J=7.3 \mathrm{~Hz}$, $3 \mathrm{H}), 0.89(\mathrm{~d}, J=6.7 \mathrm{~Hz}, 3 \mathrm{H}) ;{ }^{13} \mathrm{C} \mathrm{NMR}\left(75 \mathrm{MHz}, \mathrm{CD}_{3} \mathrm{OD}\right) \delta 172.6,166.9,161.9,159.6$, 150.0, 142.2, 139.2 135.9, 121.7, 115.9, 82.1, 75.8, 70.8, 70.6, 69.4, 68.9, 56.5, 52.6, 42.6, 41.0, 40.9, 40.5, 38.8, 37.0, 35.8, 30.0, 29.0, 26.4, 21.5, 19.8, 14.2; IR (film) 2923, 2854, $1716,1519,1458,1375,1249,1179,1103,817 \mathrm{~cm}^{-1}$; HRMS (ESI) calcd. for $\mathrm{C}_{31} \mathrm{H}_{46} \mathrm{~N}_{2} \mathrm{O}_{9} \mathrm{Na}\left([\mathrm{M}+\mathrm{Na}]^{+}\right): 613.3101$, found 613.3075; $[\alpha]_{\mathrm{D}}{ }^{25}=+0.2(\mathrm{MeOH}, \mathrm{c}=0.20)$.

\subsection{8 (1R,5S,7R,9R,10S,11S)-9,10-dihydroxy-7-methoxy-9-methyl-5-} propyl-4,15-dioxa-bicyclo[9.3.1] pentadecane-3,13-dione (30)- $\mathrm{To}^{-\mathrm{OsO}_{4}}(6.1 \mathrm{mg}$, $0.024 \mathrm{mmol})$ and pyridine $(61 \mu \mathrm{L}, 0.76 \mathrm{mmol})$ in THF $(0.2 \mathrm{~mL})$ at $0{ }^{\circ} \mathrm{C}$ was added $25(5.3$ $\mathrm{mg}, 0.016 \mathrm{mmol})$ in THF $(0.2 \mathrm{~mL})$. After $10 \mathrm{~min}, \mathrm{NMO} \cdot \mathrm{H}_{2} \mathrm{O}(4.3 \mathrm{mg}, 0.032 \mathrm{mmol})$ was added and the reaction was allowed to room temperature over $30 \mathrm{~min}$. The reaction was quenched by $1 \mathrm{~mL}$ saturated $\mathrm{Na}_{2} \mathrm{~S}_{2} \mathrm{O}_{3}$ at $0{ }^{\circ} \mathrm{C}$ and extracted with three $2 \mathrm{~mL}$ portions of EtOAc. The organic layer was concentrated under vacuum and purified by flash column chromatography (5\% $\mathrm{MeOH}$ in $\mathrm{CH}_{2} \mathrm{Cl}_{2}$ ) to afford the diol $(4.4 \mathrm{mg}, 75 \%)$. ${ }^{1} \mathrm{H}$ NMR (300 $\left.\mathrm{MHz}, \mathrm{CDCl}_{3}\right) \delta 5.03-5.14(\mathrm{~m}, 1 \mathrm{H}), 4.04(\mathrm{tt}, J=3.4,11.2 \mathrm{~Hz}, 1 \mathrm{H}), 3.66(\mathrm{tt}, J=3.0,11.2 \mathrm{~Hz}$, $1 \mathrm{H}), 3.59$ (s, 1H), 3.54-3.58 (m, 1H), 3.39 (s, 3H), 3.28 (t, $J=7.4 \mathrm{~Hz}, 1 \mathrm{H}), 2.84$ (d, $J=7.2$ $\mathrm{Hz}, 1 \mathrm{H}), 2.71(\mathrm{dt}, J=1.8,15.0,1 \mathrm{H}), 2.65(\mathrm{dd}, J=3.8,14.5 \mathrm{~Hz}, 1 \mathrm{H}), 2.50(\mathrm{dd}, J=11.1,14.3$ $\mathrm{Hz}, 2 \mathrm{H}), 2.40$ (dd, $J=12.2,15.1 \mathrm{~Hz}, 1 \mathrm{H}), 2.27$ (dd, $J=11.5,13.5 \mathrm{~Hz}, 1 \mathrm{H}), 2.15$ (ddd, $J=$ $1.3,3.5,14.4 \mathrm{~Hz}, 1 \mathrm{H}), 1.92(\mathrm{dd}, J=2.9,15.2 \mathrm{~Hz}, 1 \mathrm{H}), 1.63(\mathrm{dd}, J=10.5,14.8 \mathrm{~Hz}, 2 \mathrm{H})$, $1.42-1.62(\mathrm{~m}, 2 \mathrm{H}), 1.15-1.39(\mathrm{~m}, 5 \mathrm{H}), 0.92(\mathrm{t}, J=7.3 \mathrm{~Hz}, 3 \mathrm{H}) ;{ }^{13} \mathrm{C} \mathrm{NMR}\left(75 \mathrm{MHz}, \mathrm{CDCl}_{3}\right)$ $\delta$ 205.5, 169.5, 77.8, 77.7, 73.3, 73.0, 72.9, 56.2, 47.1, 45.0, 42.7, 41.5, 38.2, 37.5, 24.8, 18.4, 13.9; IR (film) 3441, 2923, 1721, 1555, 1460, 1377, 1267, 1183, 1100, 1069, 964, 934, $817 \mathrm{~cm}^{-1}$; HRMS (ESI) calcd. for $\mathrm{C}_{18} \mathrm{H}_{30} \mathrm{O}_{7} \mathrm{Na}\left([\mathrm{M}+\mathrm{Na}]^{+}\right) 381.1889$, found 381.1902; $[\alpha]_{\mathrm{D}}^{25}=-28.5(\mathrm{MeOH}, \mathrm{c}=0.13)$.

\subsection{9. (1R,5S,7R,9R,10S,11S,13R)-9,10,13-trihydroxy-7-methoxy-9-methyl-5- propyl-4,15-dioxabicyclo[9.3.1]pentadecan-3-one-The general reduction protocol was followed with $30(3.6 \mathrm{mg}, 0.010 \mathrm{mmol})$ and $\mathrm{NaBH}_{4}(1.1 \mathrm{mg}, 0.029 \mathrm{mmol})$. Flash column chromatography $\left(5 \% \mathrm{MeOH}\right.$ in $\left.\mathrm{CH}_{2} \mathrm{Cl}_{2}\right)$ yielded the desired triol $(3.3 \mathrm{mg}, 92 \%) .{ }^{1} \mathrm{H}$ NMR (300 MHz, CD 30 OD) $\delta 5.09-5.18(\mathrm{~m}, 1 \mathrm{H}), 3.70-3.83(\mathrm{~m}, 2 \mathrm{H}), 3.49-3.55(\mathrm{~m}, 1 \mathrm{H})$, 3.46 (ddd, $J=1.7,7.1,11.1,1 \mathrm{H}), 3.32(\mathrm{~s}, 3 \mathrm{H}), 3.28(\mathrm{~s}, 1 \mathrm{H}), 2.76(\mathrm{dd}, J=4.6,14.1 \mathrm{~Hz}, 1 \mathrm{H})$, $2.30(\mathrm{dd}, J=8.8,14.1 \mathrm{~Hz}, 1 \mathrm{H}), 2.12(\mathrm{dt}, J=2.2,12.4 \mathrm{~Hz}, 1 \mathrm{H}), 1.97(\mathrm{t}, J=14.8 \mathrm{~Hz}, 2 \mathrm{H})$, $1.91-1.95(\mathrm{~m}, 1 \mathrm{H}), 1.68(\mathrm{dd}, J=10.8,14.7 \mathrm{~Hz}, 2 \mathrm{H}), 1.50-1.65(\mathrm{~m}, 3 \mathrm{H}), 1.20-1.40(\mathrm{~m}, 8 \mathrm{H})$, $0.97(\mathrm{t}, J=7.2 \mathrm{~Hz}, 3 \mathrm{H}) ;{ }^{13} \mathrm{C} \mathrm{NMR}\left(75 \mathrm{MHz}, \mathrm{CD}_{3} \mathrm{OD}\right) \delta 171.2,77.0,76.6,76.5,74.1,74.0$, 72.0, 67.5, 55.0, 45.4, 41.2, 40.6, 39.9, 37.6, 37.4, 25.6, 18.2, 12.8; IR (film) 3397, 2924, $1729,1457,1373,1263,1195,1099,1044,937,731 \mathrm{~cm}^{-1}$; HRMS (ESI) calcd. for $\mathrm{C}_{18} \mathrm{H}_{32} \mathrm{O}_{7} \mathrm{Na}\left([\mathrm{M}+\mathrm{Na}]^{+}\right): 383.2046$, found $383.2034 ;[\alpha]_{\mathrm{D}}{ }^{25}=-8.6(\mathrm{MeOH}, \mathrm{c}=0.32)$.}

4.4.10. Dihydroxyneopeltolide (31)—The general Mitsunobu acylation protocol was followed with the triol $(3.5 \mathrm{mg}, 0.01 \mathrm{mmol}), 26(4.1 \mathrm{mg}, 0.015 \mathrm{mmol})$ and $\mathrm{Ph}_{3} \mathrm{P}(4.2 \mathrm{mg}$, $0.016 \mathrm{mmol})$, and DIAD $(3.2 \mu \mathrm{L}, 0.016 \mathrm{mmol})$ in benzene $(0.2 \mathrm{~mL})$. Flash chromatography (5\% $\mathrm{MeOH}$ in $\mathrm{CH}_{2} \mathrm{Cl}_{2}$ ) yielded the desired product $(3.0 \mathrm{mg}, 50 \%) .{ }^{1} \mathrm{H} \mathrm{NMR}(300 \mathrm{MHz}$, 
$\left.\mathrm{CDCl}_{3}\right) \delta 7.40(\mathrm{~s}, 1 \mathrm{H}), 6.26-6.34(\mathrm{~m}, 2 \mathrm{H}), 6.09$ (pentet, $\left.J=6.4 \mathrm{~Hz}, 1 \mathrm{H}\right), 5.90(\mathrm{dt}, J=1.7$, $11.5 \mathrm{~Hz}, 1 \mathrm{H}), 5.57(\mathrm{br}, 1 \mathrm{H}), 5.32(\mathrm{t}, J=2.8 \mathrm{~Hz}, 1 \mathrm{H}), 5.06-5.14(\mathrm{~m}, 1 \mathrm{H}), 4.31(\mathrm{t}, J=6.1 \mathrm{~Hz}$, $2 \mathrm{H}), 4.00(\mathrm{tdd}, J=1.9,1.9,9.3 \mathrm{~Hz}, 1 \mathrm{H}), 3.69(\mathrm{~s}, 3 \mathrm{H}), 3.59-3.67(\mathrm{~m}, 2 \mathrm{H}), 3.40(\mathrm{~s}, 1 \mathrm{H}), 3.37$ $(\mathrm{s}, 3 \mathrm{H}), 3.35(\mathrm{~s}, 1 \mathrm{H}), 3.16(\mathrm{dd}, J=5.7,8.4 \mathrm{~Hz}, 1 \mathrm{H}), 3.04(\mathrm{ddt}, J=1.9,7.4,7.4 \mathrm{~Hz}, 2 \mathrm{H}), 2.90$ $(\mathrm{d}, J=6.0 \mathrm{~Hz}, 1 \mathrm{H}), 2.72(\mathrm{t}, J=7.2 \mathrm{~Hz}, 2 \mathrm{H}), 2.54(\mathrm{dd}, J=3.8,14.4 \mathrm{~Hz}, 1 \mathrm{H}), 2.36(\mathrm{dd}, J=$ $11.2,14.4 \mathrm{~Hz}, 1 \mathrm{H}), 2.01-2.11(\mathrm{~m}, 3 \mathrm{H}), 1.83(\mathrm{~d}, J=9.6 \mathrm{~Hz}, 1 \mathrm{H}), 1.68(\mathrm{dt}, J=3.0,11.5 \mathrm{~Hz}$, $1 \mathrm{H}), 1.50-1.65(\mathrm{~m}, 5 \mathrm{H}), 1.35(\mathrm{t}, J=7.3 \mathrm{~Hz}, 2 \mathrm{H}), 1.27(\mathrm{~s}, 3 \mathrm{H}), 0.91(\mathrm{t}, J=7.2 \mathrm{~Hz}, 3 \mathrm{H}) ;{ }^{13} \mathrm{C}$ NMR (75 MHz, $\left.\mathrm{CD}_{3} \mathrm{OD}\right) \delta 171.5,165.5,148.6,140.8,137.8,134.6,120.3,114.5,77.3$, 76.8, 74.0, 73.9, 73.6, 69.5, 67.6, 54.9, 45.1, 41.1, 40.1, 37.4, 34.5, 32.5, 27.5, 25.6, 24.9, 18.2, 12.8; IR (film) 3358, 2957, 2922, 2853, 2500, 1715, 1635, 1553, 1460, 1396, 1262, $1169,1095,1052,1019,816,795,780 \mathrm{~cm}^{-1}$; HRMS (ESI) calcd. for $\mathrm{C}_{31} \mathrm{H}_{46} \mathrm{~N}_{2} \mathrm{O}_{11} \mathrm{Na}([\mathrm{M}$ $\left.+\mathrm{Na}]^{+}\right)$645.2999, found 645.2996; $[\alpha]_{\mathrm{D}}{ }^{25}=-2.1(\mathrm{MeOH}, \mathrm{c}=0.16)$.

\subsubsection{2. (1S,2S,4R,6R,8S,12R,14R)-14-Hydroxy-6-methoxy-4- methyl-8- propyl-3,9,16-trioxatricyclo[10.3.1.0 ${ }^{2}, 4$ ]hexadecan-10- one (32)-To the} unsaturated lactone $(5.9 \mathrm{mg}, 0.018 \mathrm{mmol})$ and $\mathrm{NaHCO}_{3}(5.8 \mathrm{mg}, 0.069 \mathrm{mmol})$ in $\mathrm{CH}_{2} \mathrm{Cl}_{2}(1$ $\mathrm{mL})$ at $0{ }^{\circ} \mathrm{C}$ was added recrystallized $m$-CPBA $(4.5 \mathrm{mg}, 0.026 \mathrm{mmol})$. The reaction stirred at $0{ }^{\circ} \mathrm{C}$ for 4 hours and then warmed to room temperature and stirred overnight. The reaction was quenched by the addition of $0.7 \mathrm{~mL}$ saturated $\mathrm{Na}_{2} \mathrm{~S}_{2} \mathrm{O}_{3}$ and $0.7 \mathrm{~mL}$ saturated $\mathrm{NaHCO}_{3}$ at $0{ }^{\circ} \mathrm{C}$ and extracted with three $1 \mathrm{~mL}$ portions of ethyl acetate. Flash chromatography (50\% EtOAc in hexanes) afforded the epoxy alcohol $(3.4 \mathrm{mg}, 55 \%) .{ }^{1} \mathrm{H} \mathrm{NMR}\left(300 \mathrm{MHz}, \mathrm{CDCl}_{3}\right)$ $\delta 5.32-5.42$ (m, $1 \mathrm{H}), 3.8$ (br, $1 \mathrm{H}), 3.76$ (tdd, $J=1.5,3.8,10.9 \mathrm{~Hz}, 1 \mathrm{H}), 3.65$ (dd, $J=5.4,8.9$ $\mathrm{Hz}, 1 \mathrm{H}), 3.06$ (ddd, $J=2.0,8.0,10.9 \mathrm{~Hz}, 1 \mathrm{H}), 2.71(\mathrm{~d}, J=7.8 \mathrm{~Hz}, 1 \mathrm{H}), 2.58$ (dd, $J=3.8$, $15.1 \mathrm{~Hz}, 1 \mathrm{H}), 2.50(\mathrm{dd}, J=10.8,15.2 \mathrm{~Hz}, 1 \mathrm{H}), 2.25(\mathrm{dt}, J=2.4,12.4 \mathrm{~Hz}, 1 \mathrm{H}), 2.12(\mathrm{dd}, J=$ $11.2,14.6 \mathrm{~Hz}, 1 \mathrm{H}), 1.86-2.00(\mathrm{~m}, 3 \mathrm{H}), 1.43-1.62(\mathrm{~m}, 5 \mathrm{H}), 1.34(\mathrm{~s}, 3 \mathrm{H}), 1.24-1.39(\mathrm{~m}, 6 \mathrm{H})$, $0.91(\mathrm{t}, J=7.2 \mathrm{~Hz}, 3 \mathrm{H}) ;{ }^{13} \mathrm{C}$ NMR $\left(75 \mathrm{MHz}, \mathrm{CDCl}_{3}\right) \delta 170.2,73.9,73.4,67.4,64.6,61.8$, 57.2, 44.4, 41.8, 41.6, 39.8, 39.3, 37.3, 23.3, 22.7, 18.7, 13.9; IR (film) 3435, 2924, 2854, $1732,1459,1374,1262,1200,1078,942,799 \mathrm{~cm}^{-1}$; HRMS (ESI) calcd. for $\mathrm{C}_{18} \mathrm{H}_{30} \mathrm{O}_{6} \mathrm{Na}$ $\left([\mathrm{M}+\mathrm{Na}]^{+}\right) 365.1940$, found $365.1932 ;[\alpha]_{\mathrm{D}}{ }^{25}=-23.5\left(\mathrm{CHCl}_{3}, \mathrm{c}=0.33\right)$.

4.4.13. Epoxyneopeltolide (33)—The general Mitsunobu acylation protocol was followed with 32 (3.1 mg, $0.009 \mathrm{mmol}$ ), 26 (11.2 mg, $0.040 \mathrm{mmol}$ ), $\mathrm{Ph}_{3} \mathrm{P}$ (11.4 mg, 0.044 $\mathrm{mmol})$ and DIAD $(8.6 \mu \mathrm{L}, 0.044 \mathrm{mmol})$. Flash column chromatography (30\% EtOAc in $\mathrm{CH}_{2} \mathrm{Cl}_{2}$ ) yielded epoxyneopeltolide (3.6 mg, 66\%). ${ }^{1} \mathrm{H} \mathrm{NMR}\left(300 \mathrm{MHz}, \mathrm{CD}_{3} \mathrm{OD}\right) \delta 7.65(\mathrm{~s}$, $1 \mathrm{H}), 6.36(\mathrm{dt}, J=4.1,7.3 \mathrm{~Hz}, 1 \mathrm{H}), 6.27(\mathrm{dt}, J=2.1,11.9 \mathrm{~Hz}, 1 \mathrm{H}), 6.03$ (pentet, $J=6.0 \mathrm{~Hz}$, $1 \mathrm{H}), 5.89(\mathrm{dt}, J=1.6,11.6 \mathrm{~Hz}, 1 \mathrm{H}), 5.27-5.39(\mathrm{~m}, 1 \mathrm{H}), 5.28(\mathrm{t}, J=3.0 \mathrm{~Hz}, 1 \mathrm{H}), 4.30$ (dd, $J$ $=1.8,6.1 \mathrm{~Hz}, 2 \mathrm{H}), 4.08-4.18(\mathrm{~m}, 1 \mathrm{H}), 3.72(\mathrm{dd}, J=5.3,10.0 \mathrm{~Hz}, 1 \mathrm{H}), 3.65(\mathrm{~s}, 3 \mathrm{H}), 3.34-$ $3.42(\mathrm{~m}, 1 \mathrm{H}), 3.37$ (s, 3H), 3.00 (ddd, $J=1.7,7.4,7.4 \mathrm{~Hz}, 2 \mathrm{H}), 2.71(\mathrm{t}, J=7.1 \mathrm{~Hz}, 2 \mathrm{H})$, 2.63-2.70 (m, 2H), $2.33(\mathrm{dd}, J=11.6,15.2 \mathrm{~Hz}, 1 \mathrm{H}), 2.04(\mathrm{dd}, J=10.4,14.7 \mathrm{~Hz}, 2 \mathrm{H}), 1.74$ 1.96 (m, 4H), 1.47-1.66 (m, 4H), 1.26-1.40 (m, 4H), 1.30 (s, 3H), 0.93 (t, $J=7.3 \mathrm{~Hz}$, $3 \mathrm{H}) ;{ }^{13} \mathrm{C}$ NMR $\left(75 \mathrm{MHz}, \mathrm{CD}_{3} \mathrm{OD}\right) \delta 172.4,166.7,161.9,150.2,142.2,139.1,136.0,121.6$, 116.0, 77.8, 74.9, 72.2, 68.2, 66.1, 63.0, 57.0, 44.8, 42.7, 42.0, 38.4, 35.4, 34.9, 29.0, 26.4, 23.7, 19.7, 14.1; IR (film) 3352, 2960, 2924, 1724, 1644, 1521, 1440, 1380, 1266, 1253, $1173,1126,1077,1006,968,778 \mathrm{~cm}^{-1}$; HRMS (ESI) calcd. for $\mathrm{C}_{31} \mathrm{H}_{46} \mathrm{~N}_{2} \mathrm{O}_{10} \mathrm{Na}([\mathrm{M}$ $\left.+\mathrm{Na}]^{+}\right) 627.2894$, found 627.2910; $[\alpha]_{\mathrm{D}}{ }^{25}=-11.3(\mathrm{MeOH}, \mathrm{c}=0.34)$.

\section{Supplementary Material}

Refer to Web version on PubMed Central for supplementary material. 


\section{Acknowledgments}

We thank the National Institutes of Health (GM062924) for generous support of this work. We thank Dr. Steve Geib for crystallographic analysis.

\section{References and notes}

1. Wright AE, Botelho JC, Guzman E, Harmody D, Linley P, McCarthy PJ, Pitts TP, Pomponi SA, Reed JK. J Nat Prod. 2007; 70:412. [PubMed: 17309301]

2. a) D'Ambrosio M, Guerriero A, Debitus C, Pietra F. Helv Chim Acta. 1996; 79:51. b) D'Ambrosio M, Tató M, Poscfalvi G, Debitus C, Pietra F. Helv Chim Acta. 1999; 82:347.

3. a) Hornberger KR, Hamblett CL, Leighton JL. J Am Chem Soc. 2000; 122:12894. b) Kopecky DJ, Rychnovsky SD. J Am Chem Soc. 2001; 123:8420. [PubMed: 11516301] c) Wipf P, Reeves JT. Chem Commun. 2002:2066. d) Fettes A, Carreira EM. Angew Chem, Int Ed. 2002; 41:4098. e) Fettes A, Carreira EM. J Org Chem. 2003; 68:9274. [PubMed: 14629147] f) Wang Y, Janjic J, Kozmin SA. J Am Chem Soc. 2002; 124:13670. [PubMed: 12431085] g) Wang Y, Janjic J, Kozmin SA. Pure Appl Chem. 2005; 77:1161. h) Paterson I, Tudge M. Angew Chem, Int Ed. 2003; 42:343. i) Paterson I, Tudge M. Tetrahedron. 2003; 59:6833. j) Williams DR, Plummer SV, Patnaik S. Angew Chem, Int Ed. 2003; 42:3934. k) Williams DR, Patnaik S, Plummer SV. Org Lett. 2003; 5:5035. [PubMed: 14682758] 1) Crimmins MT, Siliphaivanh P. Org Lett. 2003; 5:4641. [PubMed: 14627404] m) Su Q, Panek JS. Angew Chem, Int Ed. 2005; 44:1223. n) Su Q, Dakin LA, Panek JS. J Org Chem. 2007; 72:2. [PubMed: 17194076] o) Ferrié L, Reymond S, Capdevielle P, Cossy J. Org Lett. 2007; 9:2461. [PubMed: 17536809] p) Van Orden LJ, Patterson BD, Rychnovsky SD. J Org Chem. 2007; 72:5784. [PubMed: 17595145] q) Jung HH, Seiders JR II, Floreancig PE. Angew Chem, Int Ed. 2007; 46:8464. r) Ferrié L, Boulard L, Pradaux F, Bouzbouz S, Reymond S, Capdevielle P, Cossy J. J Org Chem. 2008; 73:1864. [PubMed: 18229938] s) Evans PA, Andrews WJ. Angew Chem, Int Ed. 2008; 47:5426.

4. Youngsaye W, Lowe JT, Pohlki F, Ralifo P, Panek JS. Angew Chem, Int Ed. 2007; 46:9211.

5. Custar DW, Zabawa TP, Scheidt KA. J Am Chem Soc. 2008; 130:804. [PubMed: 18161979]

6. a) Woo SK, Kwon MS, Lee E. Angew Chem, Int Ed. 2008; 47:3242. b) Vintonyak VV, Maier ME. Org Lett. 2008; 10:1239. [PubMed: 18302399] c) Fuwa H, Naito S, Goto T, Sasaki M. Angew Chem, Int Ed. 2008; 47:4737. d) Ulanovskaya OA, Janjic J, Suzuki M, Sabharwal SS, Schumaker PT, Kron SJ, Kozmin SA. Nature Chem Biol. 2008; 4:418. [PubMed: 18516048] e) Paterson I, Miller NA. Chemical Commun. 2008:4708. f) Kartika R, Gruffi TR, Taylor RE. Org Lett. 2008; 10:5047. [PubMed: 18855401] g) Vintonyak VV, Kunze B, Sasse F, Maier ME. Chem Eur J. 2008; 14:11132. h) Custar DW, Zabawa TP, Hines J, Crews CM, Scheidt KA. J Am Chem Soc. 2009; 131:12406. [PubMed: 19663512] i) Kim H, Park Y, Hong J. Angew Chem, Int Ed. 2009; 48:7577. j) Guinchard X, Roulland E. Org Lett. 2009; 11:4700. [PubMed: 19775106] k) Fuwa H, Saito A, Naito S, Konoki K, Yotsu-Yamashita M, Sasaki M. Chem Eur J. 2009; 15:12807. 1) Yadav JS, Krishna GG, Kumar SN. Tetrahedron. 2010; 66:480. m) Gallon J, Reymond S, Cossy J. Comp Rend Chim. 2008; 11:1463.

7. a) Tu W, Liu L, Floreancig PE. Angew Chem, Int Ed. 2008; 47:4184. b) Liu L, Floreancig PE. Org Lett. 2009; 11:3152. [PubMed: 19552390]

8. For a preliminary account of a portion of the material in this paper, see: Tu W, Floreancig PE. Angew Chem, Int Ed. 2009; 48:4567.

9. a) Schulteelte KH, Hauser A, Ohloff G. Helv Chim Acta. 1979; 62:2673. b) Wender PA, De Brabander J, Harran PG, Jimenez JM, Koehler MFT, Lippa B, Park CM, Shiozaki M. J Am Chem Soc. 1998; 120:4534. c) Wender PA, DeChristopher BA, Schrier AJ. J Am Chem Soc. 2008; 130:6658. [PubMed: 18452292] d) Bahnck KB, Rychnovsky SD. J Am Chem Soc. 2008; 130:13177. [PubMed: 18767844]

10. Denmark SE, Jones TK. J Org Chem. 1982; 47:4595.

11. Schaus SE, Brandes BD, Larrow JF, Tokunaga M, Hansen KB, Gould AE, Furrow ME, Jacobsen EN. J Am Chem Soc. 2002; 124:1307. [PubMed: 11841300]

12. Shen R, Lin CT, Porco JA Jr. J Am Chem Soc. 2002; 124:5650. [PubMed: 12010033]

13. Dale JA, Dull DL, Mosher HS. J Org Chem. 1969; 34:2543. 
14. Schmidt DR, Park PK, Leighton JL. Org Lett. 2003; 5:3535. [PubMed: 12967318]

15. Yu CM, Choi HS, Yoon SK, Jung WH. Synlett. 1997:889.

16. a) Wei SY, Tomooka K, Nakai T. J Org Chem. 1991; 56:5973. b) Maleczka RE Jr, Geng F. Org Lett. 1999; 1:1111. [PubMed: 10825963] c) Clark JS, Fessard TC, Wilson C. Org Lett. 2004; 6:1773. [PubMed: 15151411]

17. a) Sonogashira K, Todah Y, Hagihara N. Tetrahedron Lett. 1975:4467. b) Chinchilla R, Nájera C. Chem Rev. 2007; 107:874. [PubMed: 17305399]

18. a) Marshall JA, Yanik MM. Org Lett. 2000; 2:2173. [PubMed: 10891259] b) Burova SA, McDonald FE. J Am Chem Soc. 2004; 126:2495. [PubMed: 14982459] c) Trost BM, Ball ZT, Laemmerhold KM. J Am Chem Soc. 2005; 127:10028. [PubMed: 16011365] d) Robles O, McDonald FE. Org Lett. 2008; 10:1811. [PubMed: 18399654]

19. Denmark SE, Wang Z. Org Lett. 2001; 3:1073. [PubMed: 11277798]

20. Tamao K, Maeda K, Tanaka T, Ito Y. Tetrahedron Lett. 1988; 29:6955.

21. Denmark SE, Pan W. Org Lett. 2002; 4:4163. [PubMed: 12423112]

22. Evans DA, Hoveyda AH. J Am Chem Soc. 1990; 112:6447.

23. Inanaga J, Hirata K, Saeki H, Katsuki T, Yamaguchi M. Bull Chem Soc Jpn. 1979; 52:1989.

24. a) Goossen LJ, Paetzold J, Koley D. Chem Commun. 2003:706. b) Neveux M, Bruneau C, Dixneuf PH. J Chem Soc, Perkin Trans 1. 1991:1197.

25. Jung HH, Floreancig PE. Tetrahedron. 2009; 65:10830. [PubMed: 20640173]

26. a) Tolbert LM, Khanna RK, Popp AE, Gelbaum L, Bottomley LA. J Am Chem Soc. 1990; 112:2373. b) Perrott AL, de Lijser HJP, Arnold DR. Can J Chem. 1997; 75:384. c) Freccero M, Pratt A, Albini A, Long C. J Am Chem Soc. 1998; 120:284. d) Floreancig PE. Synlett. 2007:191.

27. CCDC721650 contains the supplimentary crystallographic data for this paper. These data can be obtained free of charge from the Cambridge Crystallographic Data Centre via www.ccdc.cam.ac.uk/data_request/cif.

28. Mitsunobu O. Synthesis. 1981:1.

29. Wipf P, Graham TH. J Org Chem. 2001; 66:3242. [PubMed: 11325299]

30. Crabtree RH, Davis MW. J Org Chem. 1986; 51:2655.

31. Hoveyda AH, Evans DA, Fu GC. Chem Rev. 1993; 93:1307.

32. For recent discussions, see: a) Trost BM, Weiss AH. Angew Chem, Int Ed. 2007; 46:7664. b) Trost BM, Sieber JD, Qian W, Dhawan R, Ball ZT. Angew Chem, Int Ed. 2009; 48:5478. 


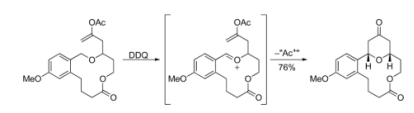

Scheme 1.

Oxidative cyclization through a macrocyclic oxocarbenium ion. 
3

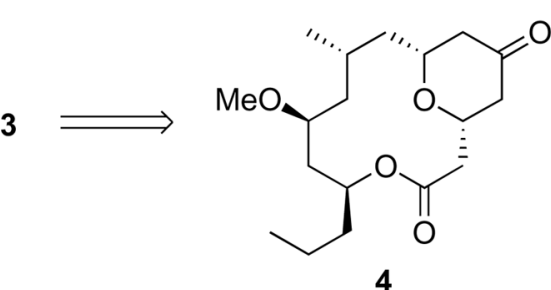<smiles>C=C=CCO[C@@H](CC(=O)O[C@H](CCC)C[C@@H](CC(=C)OC)OC(C)=O)C/C(C)=C\C</smiles>

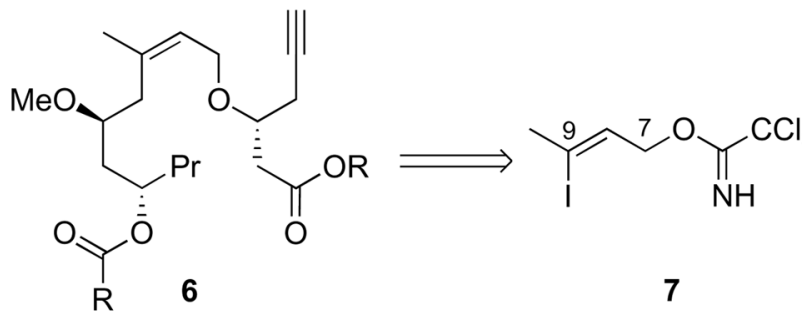<smiles>CCC[C@H]1CO1</smiles>

Scheme 2.

Retrosynthetic analysis of neopeltolide. 


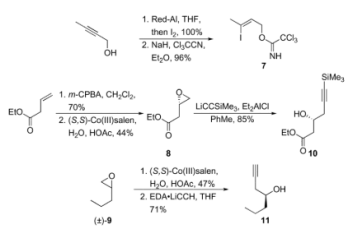

Scheme 3.

Subunit preparation. 


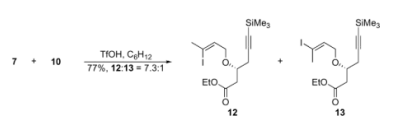

Scheme 4.

TfOH-mediated etherification. 


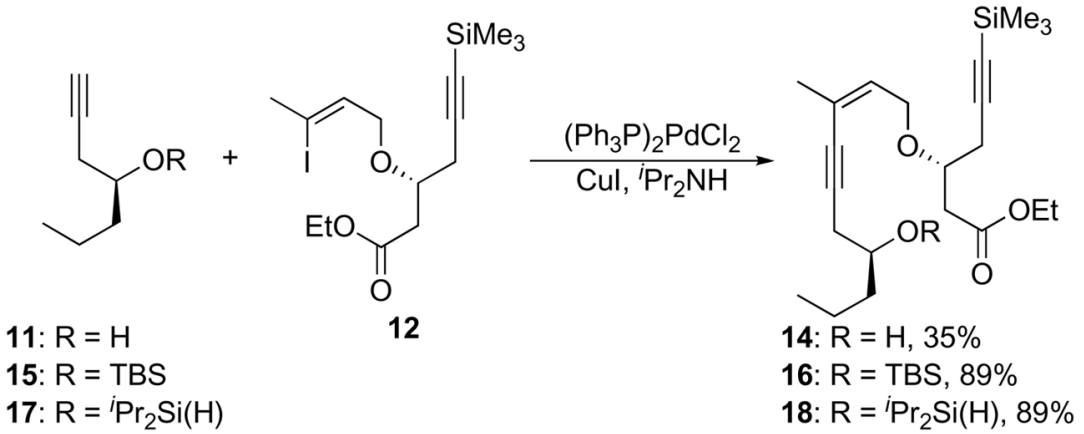

Scheme 5.

Sonogashira coupling. 


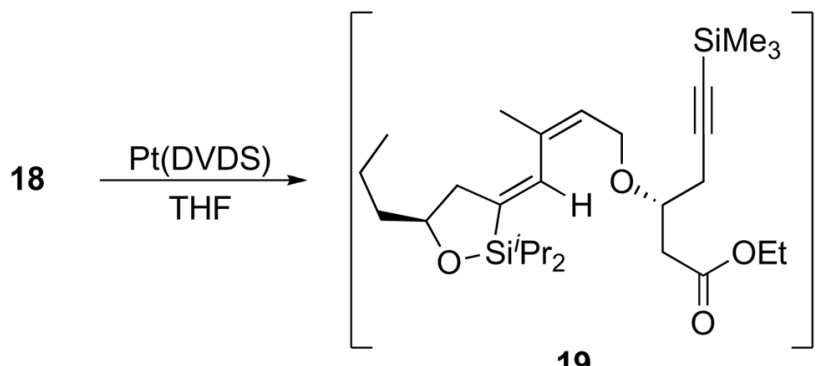

19
$\mathrm{Bu}_{4} \mathrm{NF}, \mathrm{KF}, \mathrm{KHCO}_{3}$

$\underset{\mathrm{H}_{2} \mathrm{O}_{2}, \mathrm{THF}, \mathrm{DMF}}{\stackrel{40}{ }{ }^{\circ} \mathrm{C}, 57 \%,}$

20:21 = 11:1

Scheme 6 .

Alkyne hydration through hydrosilylation. 


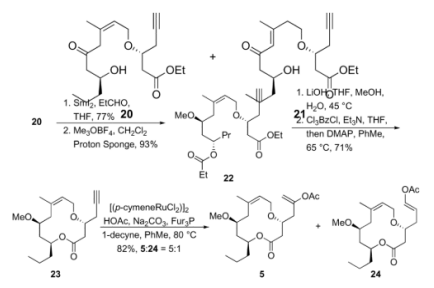

Scheme 7.

Completion of the cyclization substrate synthesis. 


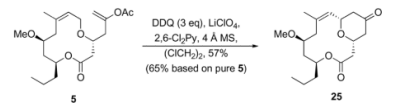

Scheme 8.

Oxidative cyclization. 

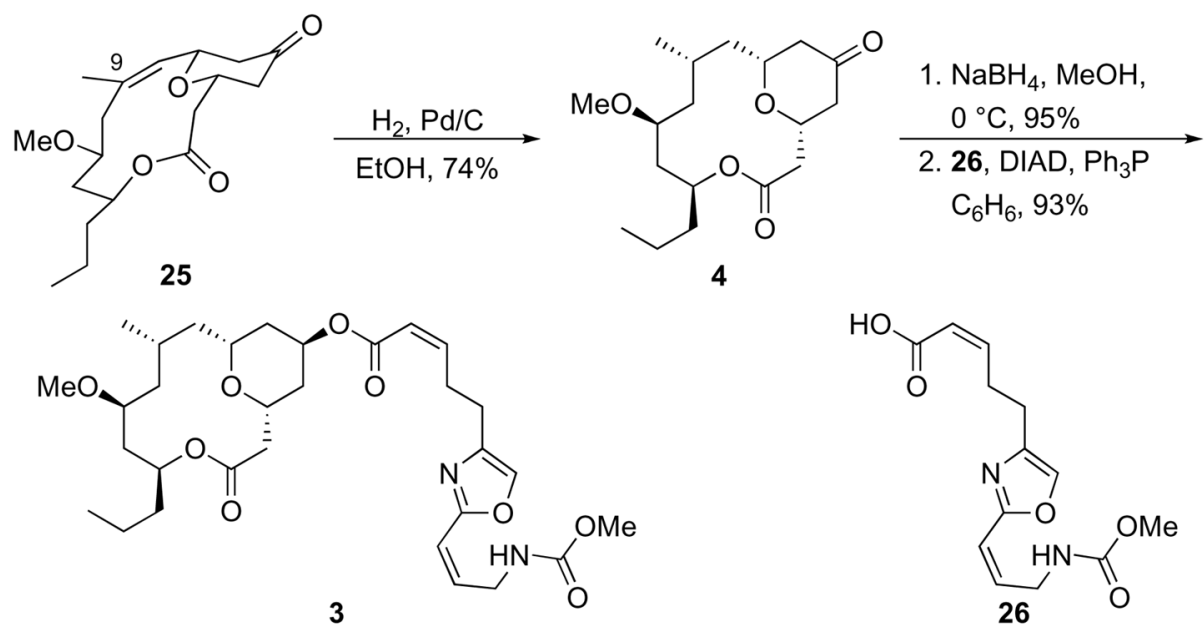

Scheme 9.

Synthesis of neopeltolide. 
25

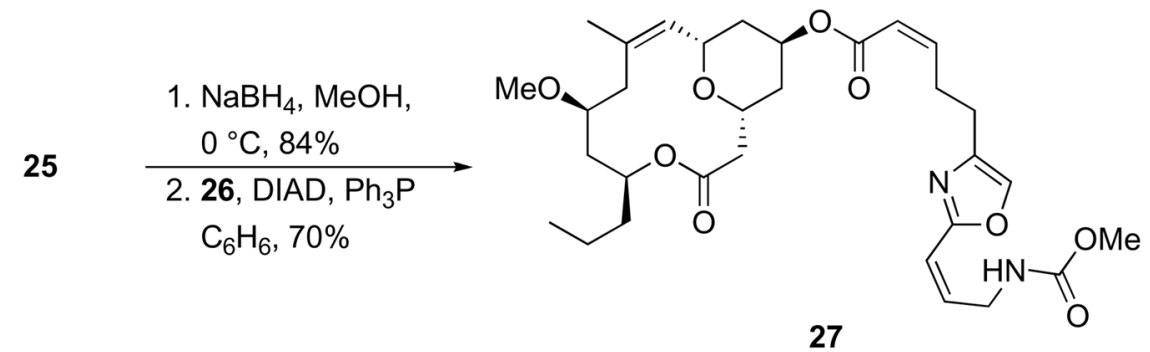

Scheme 10.

Synthesis of dehydroneopeltolide. 


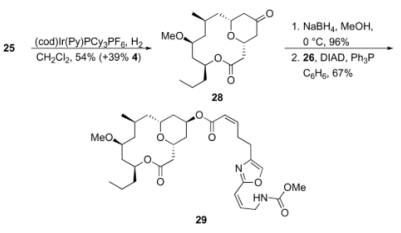

Scheme 11.

Synthesis of 9-epi-neopeltolide. 
25
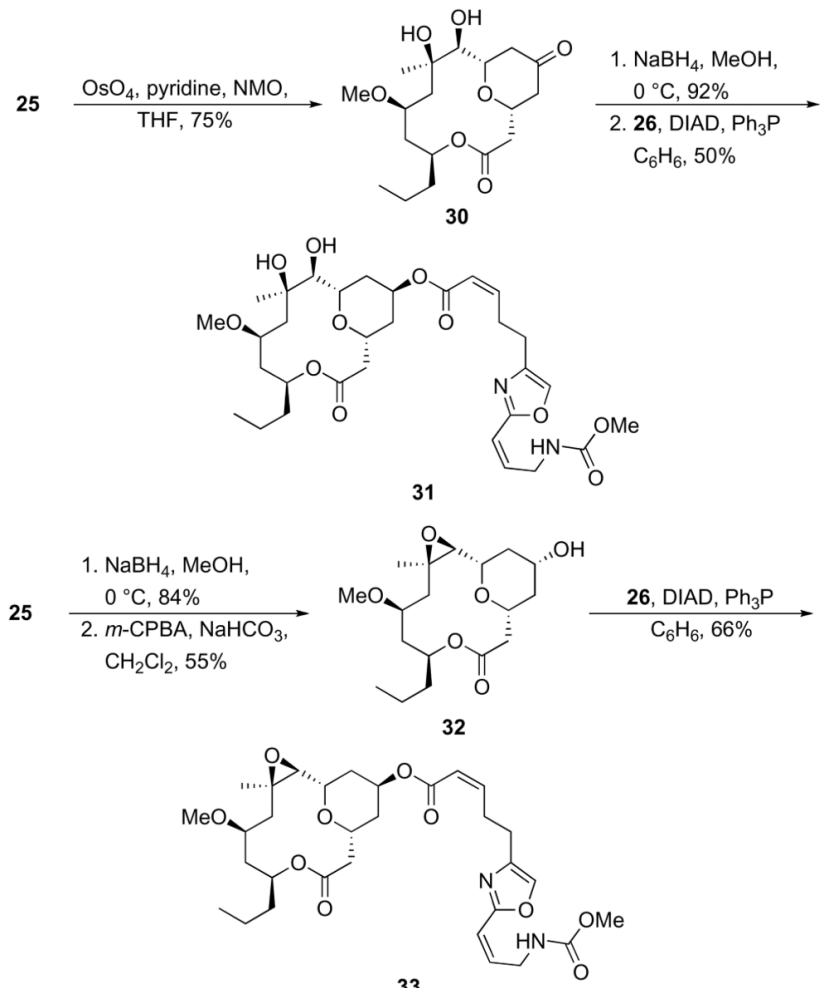

33

Scheme 12.

Synthesis of dihydroxy- and epoxyneopeltolide. 